\title{
What Motivates Software Piracy in China: Q-Methodology Perspective
}

\author{
Chanwoo Kim*, Mao Xuewen**, Hyosung Park***, \\ and Kwangho Jung****
}

\begin{abstract}
This study explores why Chinese consumers use pirated software programs and how they think about their illegal use, relying on Q methodology. We developed $32 \mathrm{Q}$ statements that outline reasons for using pirated software and surveyed 30 respondents from public officials, and software companies employees to students, professors, researchers, and the public. We developed four Q factors to describe four types of response to the use of pirated software. One group addresses a normative legal response, the second makes an economic utility argument, the third calls for punishing violators, and the fourth claims that they find themselves facing an uncomfortable dilemma in having to choose between the cheapness of illegal software and its illegality. Chinese respondents believe that government intervention can reduce the extent of illegal use (normative legal) and that intellectual property should be protected (economic utility). Furthermore, they acknowledged that the illegal use of software is a socio-structural problem across all social groups rather than a problem of a specific demographic group, such as a group of teenagers. Future research is required to explore not only whether or not perceptions regarding the use of illegal software vary from country to country but also how Confucian culture and norms are related to attitudes about the widespread use of counterfeit products in Asian countries.
\end{abstract}

Keywords: software piracy, Q methodology, comparative cultural analysis

* Chanwoo Kim is a PhD candidate in the Graduate School of Public Administration, Seoul National University. Email: carfedm@snu.ac.kr.

** Mao Xuewen is a professor in the School of Management at Lanzhou University. Email: mxw5885@163.com.

*** Hyosung Park is a master's student in Graduate School of Public Administration, Seoul National University. Email: estherpkim@snu.ac.kr.

**** Kwangho Jung, corresponding author, is a professor at the Korea Institute of Public Affairs and the Institute of Information, Knowledge and Public Policy at Graduate School of Public Administraton, Seoul National University. Email: kwjung77@gmail.com.

Manuscript received June 23, 2017; out for review July 14, 2017; review completed August 18, 2017; accepted August 28, 2017.

The Korean Journal of Policy Studies, Vol. 32, No. 2 (2017), pp. 135-166.

(C) 2017 by the GSPA, Seoul National University 


\section{INTRODUCTION}

The purpose of this study is to analyze why Chinese people use illegal software and how they perceive this illegal use by drawing on Q methodology. This study particularly focuses on users' deep-seated intentions. The reason why this study uses Q methodology can also be understood in this context. We review the literature on why people use an illegal software and how perceive the illegal behavior legally, economically, and morally and explain how Q methodology can be used to examine what perspectives are embedded in perceptions of the widespread illegal use of software in China. Relying on various sources, including interviews with Chinese government officials, software providers, office clerks, and researchers as well as previous papers, we generate a series of $32 \mathrm{Q}$ statements on the illegal use of software and use them to assess how our 30 Chinese respondents perceive illegal software use (P sample).

Previous research has suggested various ways of understanding software piracy and means of reducing it (Asongu et al., 2016; Higgins, 2005; Lee \& Yoo, 2009; Yoo, 2011). One approach is rational choice perspective, which focuses on deterrence efforts in reducing it (Moores \& Dhillon, 2000). Other studies have emphasized nonlegal or good governance approaches (Andrés \& Asongu, 2013; Driouchi et al., 2015). Further research has also suggested the role of cultural differences in piracy and policy instruments that might be effective against it (Asongu et al., 2016; Yoo et al., 2014). However, these findings are relevant only in certain contexts, and moreover these accounts overlap or compete with each other in their explanation of why people attempt to use pirated software. We seek to identify perceptions about illegal software use that underlie these various factors by assessing a broad range of responses to illegal software use from software providers, users, regulators, including civil servants in charge of enforcement, to software company employees who develop software, groups of professors and experts, and the public. Of course, this study is limited in its representative sample because it targets a certain minority. It is this subject to the criticism that it is not possible to generalize the results of a Q-study based on a small number of subjects, that such generalization is only possible via random sampling (Kerlinger, 1973). However, this methodology has the advantage of being able to quantitatively measure the subjective aspects of human behavior. In particular, the subjectivity of policy participants in the administrative sector has a significant impact on policy outcomes. In this respect, analysis through Q methodology is useful (Kim, 2016, p. 105). The Q methodology allows researchers to understand a given situation in a representative fashion because the subjects are confronted with various responses to it through multiple Q statements (Brown et al., 1999). In addition, since $\mathrm{Q}$ factors are groups of people with similar views, perspectives, and values, the Q 
methodology can be used to obtain a general view of these groups (Kim, 2016).

\section{SOFTWARE PIRACY IN CHINA}

In 2014, China had the highest illegal software usage rate in the world at $77 \%$. The economic damage in the country from this illegal use was estimated to be USD\$8.9 billion (Business Software Alliance, 2014). According to a survey on software piracy awareness that was commissioned by Business Software Alliance and administered to 15,000 users in 33 countries, $57 \%$ of personal PC users have illegally copied or used counterfeit software, $31 \%$ of them on a regular basis and another $25 \%$ occasionally. These numbers demonstrate the urgency of developing appropriate countermeasures against the prevalence of software piracy through education and improved management mechanisms (Business Software Alliance, 2014).

\section{Policy Efforts to Eradicate Software Piracy in China}

Using pirated software is not considered immoral by Chinese consumers (Lin, 2015), and for this reason, the problem is hard to tackle. Chinese consumers tend not to be aware of copyright law, and there are fewer penalties for illegal copying in China; moreover, individual consumers are not punished for using pirated products (Lin, 2015). These factors together contribute to China's having "the world's highest piracy rate." But Since 2000, the Chinese government has made an active effort to address the problem of China being seen as a "piracy haven." The State Council issued a "notice on the use of authorized software by government agencies and on the eradication of pirated software" in 2001 and "a notice on the use of authorized software by local governments" in 2004. In 2012, the State Council organized a "luncheon meeting to promote the use of authorized software" in 15 departments. Its purpose was to organize the use of authorized software among local governments by the end of 2013 (Son, 2012).

The efforts of the Chinese government enabled 135 national institutions to install authorized software by May 2011. By June 2012, 31 provinces across the country had installed authorized software. The private sector, however, has faced difficulties in promoting the use of authorized software (Son, 2012). Due to the lack of enforcement in the civilian sector and the difficulty of supervision, it is estimated that there is still much unauthorized use of software in the private sector. It is the policies of the Chinese government that account for the difference between the public sector and the private sector when it comes to illicit software use rather than any difference between 
public and private sector employees. It was only in 2006 that the central government and the State Council decided to actively promote the use of authorized software by companies. In February 2007, nine departments, including the National Copyright Office, came together to form a "practical consultative body on the use of authorized software by enterprises." The difference in the use of authorized software between public and private sectors thus arises from the fact that private companies were the last to be targeted by the state council (Son, 2012, pp. 1-2) and from the fact that foreign software companies have distributed or supported illegal software in order to maintain their monopoly position in the Chinese market. The private sector is not as closely supervised by the central government as is the public sector, and so the private sector has more opportunity to use illegal software distributed by foreign companies (Son, 2012).

\section{Theories Regarding the Use of Illegal Software}

Recent studies on the use of illegal software come mainly from the fields of economics and business administration, sociology, and criminal law. Theories can be broadly divided into four categories: expected utility theory, deterrence theory, social learning theory, and positive general prevention theory.

Expected utility theory holds that individuals build their expectations based on consistent preferences and maximize their expected utility by minimizing risks in a given situation (Gopal \& Sanders, 1988, 2000). To maximize the expected utility, the individual chooses the less expensive option if it is as effective as more expensive ones and the more effective one if all options cost the same. Deterrence theory maintains that individuals make a decision about whether to engage in illegal activities by comparing the benefits of those activities with the punishment they can be expected to receive if those activities are detected (Gibbs, 1975, p. 58). In other words, an individual is less likely to commit a crime if the certainty and severity of punishment is high.

According to the deterrence theory, then, the greater the perceived threat of punishment for using illegal software, the less likely it is the individual will engage in piracy (Nill \& Schibrowsky, 2010). While expected utility theory and deterrence theory focus on individual psychology, social learning theory focuses on how individuals respond to the environment (Yoon, 2004). Because individuals learn about crime through environmental influences, how to control these influences is an important

1. National Copyright Administration Bureau, Ministry of Information Industry, Department of Commerce, Ministry of Finance, State-Owned Asset Management Committee, National Federation of Commerce, Bank Supervisory Board, Securities Supervisory Board. 
factor in crime prevention. Individuals learn through contact with their surroundings, by being compensated for good behavior and punished for bad behavior, and by imitating others (Yoon, 2004). According to positive general prevention theory, the government seeks to prevent crime by changing consciousness through education (Hong, 2015). This theory argues that individuals internalize norms through education, while social learning maintains that they absorb them through their interaction with their environment (Yoon, 2004).

\section{RESEARCH METHOD AND SUBJECTS}

\section{Q Methodology}

Q methodology is a quantitative technique for evaluating human subjectivity (Stephenson, 1953; Brown, 1980). The methodology, which received attention with the emergence of postbehaviorism, enables analysis of the deep-seated, subjective opinions of research subjects (Kim, 2007). Because software piracy is illegal, people who engage in it are not inclined to express their personal opinions openly. Q methodology is a tool that can help us see inside the subjective world of research subjects who use illegal software. Procedurally, a Q analysis consists of the creation of Q statements, the selection of $\mathrm{P}$ samples, and Q sorting.

\section{Design of Sample Statements}

The statements used in this study were drafted based on previous research and interviews with subjects regarding software piracy. While previous studies focused more on verifying one theory or another, this study seeks to test multiple theories simultaneously. Table 1 lists the 32 statements that taken together reflect the four theories we have outlined. ${ }^{2}$

Statements 1-4, 14, 21, and 29 reflect the perspective of expected utility theory. These statements relate to the price of authorized products, the convenience of purchasing pirated software, the quality of illegal software, the time it takes to purchase authorized products, and ease of use of authorized as opposed to illegal copies of software. There are many domestic and international studies explaining the use of

2. This study is a follow-up study of a study on software piracy in Korea. For this reason, this study uses the same statements as the first study. For more information, see Kim and Jung 2016. 
illegal software in terms of expected utility (Gopal \& Sanders, 1998; Douglas, Cronan, \& Behel, 2007; Kim, 2004; Yu, Kim, \& Choi, 2008).

Statements 6, 7, 9, 18-20, and 22 reflect the perspective of deterrence theory. These statements reference poor enforcement, certainty that authorized use will be encouraged by improved enforcement and knowledge on the part of potential pirates of the severity of punishment, the importance of education and publicity in preventing use of illegal software, and the role of technology in detecting use of illegal software. Deterrence theory accounts for illegal software use in terms of rational choice. These statements draw on domestic and international research on deterrence theory (Gibbs, 1975; Nill \& Schibrowsky, 2010; Yoon, 2004; Lee, 2011).

Statements 5, 10,11, 13, 24, and 25 reflect the perspective of social learning theory. The use of counterfeit software is common; it is a structural societal problem. Usage of illegal software is encouraged through socialization, by the practices of friends and communities.

We formulated statements $16,23,28$, and 30 based on studies that examined software piracy from an economic standpoint. The statements reference the effect of illegal software use on related industries, the importance of intellectual property rights and their connection with unemployment, and the overpricing of authorized products. Considering the fact that the most common reason for using illegal software is the high price of authorized software, the economic point of view is important. This study also uses these items in attempt to test the extent to which the respondent group accepts such economic perspectives (Jo, 2010).

Statements $8,12,15,26,31$, and 32 were devised based on interviews and related news articles. These statements refer to purchasing unauthorized software for testing purposes and out of simple curiosity, to a belief that the first distributor of illegal software is more responsible than those who subsequently use it, and to the notion that the issue resolve itself in time.

Table 1. List of $Q$ Statements

\begin{tabular}{c|l}
\hline Number & \multicolumn{1}{c}{ Q statements } \\
\hline 1 & $\begin{array}{l}\text { I have no choice but to use illegal copies of software because the authorized } \\
\text { product is too expensive. }\end{array}$ \\
\hline 2 & $\begin{array}{l}\text { It is more convenient to download illegal copies from the internet than to buy the } \\
\text { authorized product. }\end{array}$ \\
\hline 3 & The quality of counterfeit software is almost equal to that of authorized software. \\
\hline
\end{tabular}




\begin{tabular}{|c|c|}
\hline 4 & $\begin{array}{l}\text { Although I can afford to purchase licensed software, I would rather spend the } \\
\text { money on somewhere else. }\end{array}$ \\
\hline 5 & The use of pirated software is common and is not limited to particular individuals. \\
\hline 6 & $\begin{array}{l}\text { I do not think my use of pirated software will be detected and thus feel safe from } \\
\text { punishment via copyright enforcement. }\end{array}$ \\
\hline 7 & $\begin{array}{l}\text { Improved detection of counterfeit software will increase the purchase of authorized } \\
\text { software. }\end{array}$ \\
\hline 8 & I buy illegal copies for a test run before purchasing authorized software. \\
\hline 9 & $\begin{array}{l}\text { The certainty of being punished for software copyright violation will surely lead to } \\
\text { an increase in the use of licensed software products. }\end{array}$ \\
\hline 10 & $\begin{array}{l}\text { It is unfair that I should have to use authorized products while others use } \\
\text { counterfeit products. }\end{array}$ \\
\hline 11 & $\begin{array}{l}\text { The reason why people use illegal copies of software is a social rather than } \\
\text { personal problem. }\end{array}$ \\
\hline 12 & I use illegal copies just out of curiosity. \\
\hline 13 & $\begin{array}{l}\text { Although I generally do not intend to use counterfeit software, I end up using it at } \\
\text { the suggestion of people around me. }\end{array}$ \\
\hline 14 & $\begin{array}{l}\text { I use counterfeit software because it takes too long for authorized products to be } \\
\text { distributed. }\end{array}$ \\
\hline 15 & $\begin{array}{l}\text { When it comes to software piracy, the fault of the first distributor of the pirated } \\
\text { copy is greater than that of downloaders. }\end{array}$ \\
\hline 16 & $\begin{array}{l}\text { Growing use of pirated software will contract the relevant industry, resulting in a } \\
\text { reduction in jobs. }\end{array}$ \\
\hline 17 & $\begin{array}{l}\text { No matter how expensive, we must use authorized products instead of pirated } \\
\text { software. }\end{array}$ \\
\hline 18 & More stringent punishment will greatly reduce the use of pirated software. \\
\hline 19 & $\begin{array}{l}\text { To increase the likelihood of detection, the manpower, organization, and budget } \\
\text { of the relevant enforcement bodies need to be beefed up. }\end{array}$ \\
\hline 20 & $\begin{array}{l}\text { In order to establish the use of authorized products as a cultural norm, persuasion } \\
\text { and understanding through education and publicity must be prioritized over legal } \\
\text { enforcement and punishment. }\end{array}$ \\
\hline 21 & $\begin{array}{l}\text { I try to use authorized products whenever I can because using pirated software } \\
\text { often causes unnecessary inconveniences. }\end{array}$ \\
\hline 22 & $\begin{array}{l}\text { Using information technology that facilitates detection of software piracy will solve } \\
\text { the problem more effectively than other means. }\end{array}$ \\
\hline 23 & $\begin{array}{l}\text { Intellectual property rights must be strictly protected, and doing so will result in } \\
\text { enhanced quality of life. }\end{array}$ \\
\hline
\end{tabular}




\begin{tabular}{c|l}
\hline 24 & $\begin{array}{l}\text { The use of counterfeit software is not pervasive throughout society but rather is } \\
\text { limited to a segment that includes youth. }\end{array}$ \\
\hline 25 & $\begin{array}{l}\text { The press exaggerates about the use of illegal copies of software, and people } \\
\text { overestimate the graveness of the problem. }\end{array}$ \\
\hline 26 & $\begin{array}{l}\text { Using illegal copies is different from stealing; I don't feel guilty when I use } \\
\text { counterfeit software. }\end{array}$ \\
\hline 27 & $\begin{array}{l}\text { The replication and distribution of software without permission is unlawful and } \\
\text { morally wrong. }\end{array}$ \\
\hline 28 & $\begin{array}{l}\text { Economic crises and increasing unemployment force many people to illegally } \\
\text { copy and distribute software for money. }\end{array}$ \\
\hline 30 & $\begin{array}{l}\text { Purchasing an authorized product seems to be a losing proposition, since the } \\
\text { products will be updated with newer versions soon after. }\end{array}$ \\
\hline
\end{tabular}

\section{Design of P Sample}

The purpose of this study is to analyze the perception of illegal software use and to draw conclusions from that analysis that might guide future policy. To that end, we not only included illegal software users in the study's P sample but also experts on illegal software use and enforcement officers because they participate in the policy process. Given that all 30 respondents answered that they had used illegal software more than once in their preliminary interview, however, all of them could have been included in the "user" category as well. The greatest number of illegal software users was found among the respondents in their twenties and thirties (52\% and 25\% respectively), and so this study focuses on that age range. ${ }^{3}$ The exact composition of the P sample is shown in table 2.

Table 2. -P Samples

\begin{tabular}{c|l}
\hline Occupation & $\begin{array}{l}\text { Government Officials (General Public Servants, 2); Police, 3; } \\
\text { Software Company Employees, 4; Professors and Researchers, 5; } \\
\text { College Students, 13; Office Clerks, 3 }\end{array}$ \\
\hline Age & 20s (13), 30s (9), 40s (7), 50s (1) \\
\hline Gender & Male (17), Female (13) \\
\hline Total Respondents & 30 \\
\hline
\end{tabular}

3. The ratios for all other age groups were as follows: teens, $4 \%$; forties, $11 \%$; fifties, $6 \%$; and sixties and older, $2 \%$ (Jo, 2010). 


\section{Q-Sorting Procedure}

There are two ways to sort Q statements: by forced distribution or by free sorting. In forced distribution, participants are asked to sort the statements according to their subjective significance and rank them by from "strongly disagree" (-4) to "strongly agree" $(+4)$. Respondents put statements that they do not feel strongly about one way other are assigned a value of 0 . The result is a set of statements with a normal distribution around zero and a standard deviation (Brown, 1980). On the other hand, the free-sorting method allows respondents to freely distribute the statements (Kim, 2007: 50).

This study employs the forced distribution method because of the advantage a set of normally distributed answers provides. Specifically, respondents were asked to assign the $32 \mathrm{Q}$ statements onto 32 spaces as shown in figure 1. A conventional 9-point scale was used with -4 representing "strongly disagree" and +4 representing the "strongly agree." The ordered statements provided by the 30 different respondents were entered into the PQMethod (2002), which automatically generated normally distributed values (including frequency) through factor rotation. Table 3 is an analysis table that shows the results.

Figure 1. Questionnaire for $Q$ classification

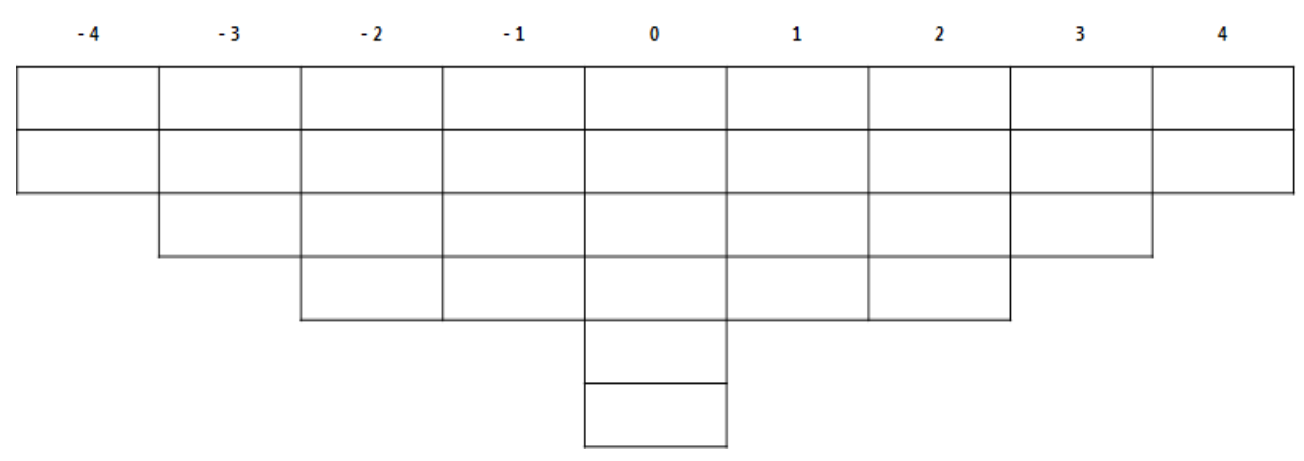

EMPIRICAL RESULTS

\section{Classification among Different Perception Types}

When performing a $\mathrm{Q}$ analysis, the researcher can arbitrarily specify the factors. When designating a factor, the researcher usually conducts a $\mathrm{Q}$ analysis by specifying 
three to five factors and then selects the factors with the highest total explanatory power (Kim, 2008). In China, as shown in table 3, the explanatory power of each factor was $20 \%, 15 \%, 10 \%$, and $9 \%$, respectively, with a total explanatory power of $54 \%$. The breakdown among the 30 Chinese respondents is as follows: factor 1, 10; factor 2, 9; factor 3, 4; and factor 4, 3 .

Table 3. Factor Analysis

\begin{tabular}{|c|c|c|c|c|c|c|c|}
\hline & Factor 1 & Factor 2 & Factor 3 & Factor 4 & Profession & Age & Sex \\
\hline 1 & 0.3943 & $0.4451^{*}$ & -0.0026 & 0.1996 & college student & $20 s$ & $M$ \\
\hline 2 & $0.6570^{*}$ & 0.0422 & -0.4508 & 0.0203 & college student & $20 \mathrm{~s}$ & M \\
\hline 3 & $0.6212^{\star}$ & 0.1472 & 0.1304 & 0.5773 & college student & $20 \mathrm{~s}$ & $\mathrm{~F}$ \\
\hline 4 & $0.6064^{*}$ & 0.0503 & 0.1187 & 0.5862 & college student & $20 \mathrm{~s}$ & $\mathrm{M}$ \\
\hline 5 & 0.2419 & $0.5908^{*}$ & -0.0469 & -0.1538 & $\begin{array}{l}\text { software company } \\
\text { employee }\end{array}$ & $20 s$ & $\mathrm{~F}$ \\
\hline 6 & 0.2939 & 0.4309 & 0.0272 & $0.6012^{*}$ & $\begin{array}{c}\text { software company } \\
\text { employee }\end{array}$ & $20 \mathrm{~s}$ & M \\
\hline 7 & $0.6829^{\star}$ & 0.3445 & 0.2360 & 0.1783 & police officer & $30 \mathrm{~s}$ & $M$ \\
\hline 8 & 0.2110 & $0.4435^{*}$ & 0.0799 & 0.2844 & police officer & $30 \mathrm{~s}$ & $M$ \\
\hline 9 & $0.7513^{\star}$ & 0.1836 & 0.0994 & 0.2748 & police officer & $30 \mathrm{~s}$ & $\mathrm{~F}$ \\
\hline 10 & 0.2118 & $0.6242^{*}$ & -0.0132 & 0.1970 & researcher & $30 \mathrm{~s}$ & $M$ \\
\hline 11 & $0.4815^{\star}$ & 0.0645 & 0.0834 & -0.0043 & researcher & $30 \mathrm{~s}$ & $M$ \\
\hline 12 & 0.1567 & 0.2031 & $0.6654^{*}$ & -0.0977 & college student & $30 \mathrm{~s}$ & $M$ \\
\hline 13 & $0.6732^{*}$ & 0.3690 & -0.1117 & -0.0522 & college student & $30 \mathrm{~s}$ & $\mathrm{~F}$ \\
\hline 14 & -0.2462 & 0.3191 & -0.3755 & 0.3100 & college student & $30 \mathrm{~s}$ & $\mathrm{~F}$ \\
\hline 15 & 0.4257 & 0.4205 & 0.0665 & 0.2340 & college student & $30 \mathrm{~s}$ & $\mathrm{~F}$ \\
\hline 16 & -0.0043 & $0.7477^{\star}$ & 0.2196 & 0.1305 & college student & $30 \mathrm{~s}$ & $\mathrm{~F}$ \\
\hline 17 & 0.2020 & $0.5774^{*}$ & 0.4374 & -0.0192 & college student & $30 \mathrm{~s}$ & $M$ \\
\hline 18 & $0.6527^{\star}$ & 0.4590 & 0.3246 & -0.0958 & college student & $30 \mathrm{~s}$ & $M$ \\
\hline 19 & 0.3662 & $0.5047^{*}$ & 0.1120 & 0.2365 & office clerk & $30 \mathrm{~s}$ & $\mathrm{M}$ \\
\hline 20 & -0.0837 & $0.6754^{*}$ & 0.2238 & -0.1299 & $\begin{array}{c}\text { software company } \\
\text { employee }\end{array}$ & $30 \mathrm{~s}$ & $\mathrm{~F}$ \\
\hline 21 & -0.2340 & 0.3682 & 0.1054 & $0.5259^{*}$ & $\begin{array}{c}\text { software company } \\
\text { employee }\end{array}$ & $30 \mathrm{~s}$ & M \\
\hline 22 & 0.1083 & 0.3342 & $0.5353^{*}$ & 0.2418 & civil servant & $40 \mathrm{~s}$ & M \\
\hline 23 & 0.3573 & 0.3084 & 0.4727 & 0.3102 & civil servant & $40 \mathrm{~s}$ & $\mathrm{~F}$ \\
\hline 24 & $0.7288^{\star}$ & 0.0999 & 0.0461 & 0.1369 & professor & $40 \mathrm{~s}$ & $M$ \\
\hline 25 & 0.0682 & -0.0756 & -0.0645 & $0.6036^{*}$ & researcher & $40 \mathrm{~s}$ & $M$ \\
\hline
\end{tabular}




\begin{tabular}{c|c|c|c|c|c|c|c}
\hline $\mathbf{2 6}$ & 0.3754 & $0.6234^{\star}$ & 0.2477 & 0.2522 & student & $40 \mathrm{~s}$ & $\mathrm{M}$ \\
\hline $\mathbf{2 7}$ & 0.3827 & -0.0247 & $0.6484^{*}$ & 0.4234 & student & $40 \mathrm{~s}$ & $\mathrm{M}$ \\
\hline $\mathbf{2 8}$ & -0.3165 & 0.0754 & $0.5889^{*}$ & -0.1344 & office clerk & $40 \mathrm{~s}$ & $\mathrm{M}$ \\
\hline $\mathbf{2 9}$ & 0.3652 & 0.1629 & 0.3799 & 0.1976 & office clerk & $40 \mathrm{~s}$ & $\mathrm{~F}$ \\
\hline $\mathbf{3 0}$ & $0.7444^{*}$ & 0.0534 & 0.3597 & -0.0331 & professor & $50 \mathrm{~s}$ & $\mathrm{M}$ \\
\hline $\begin{array}{c}\text { \% } \\
\text { (Total= } \\
\mathbf{5 4}\end{array}$ & 20 & 15 & 10 & 9 & & & \\
\hline
\end{tabular}

Notes: \%= explained variance; * = statistically significant at 0.05 .

Each perception pattern is distinguished and categorized based on factor scores of the statements, as table 4 shows. In a research using Q methodology, Q factors are analyzed by examining statements to which respondents assign extreme values $(+4$, $+3,-3,-4)$ and classifying research subjects into groups based on their sharing similar viewpoints on a set topic (Brown, 1980; Kim, 2007). The factor scores shown in table 4 are for each statement and are the foundation for the classification of perception patterns outlined in the following section. Q methodology follows the same procedure for correlation analysis, factor extraction, and factor rotation as the factor analysis. However, Q methodology differs from factor analysis in that the P sample is a variable. In the traditional factor analysis, the analysis is based on the correlation among the background variables of the sample. In a Q study, however, the correlation between the P samples forms the center of analysis. Q analysis extracts the factors into groups of subject that share similar views based on the correlation between the $\mathrm{P}$ samples. In a Q study, factors are extracted via centroid analysis and principal component analysis. In a Q study, the centroid method is the primary tool, which is not the case in factor analysis. The reason for using the centroid method in a $\mathrm{Q}$ study is related to the eigenvalue. In the factor analysis, the factor is determined based on the eigenvalue, and the minimum criterion is 1 . However, the centroid approach is recommended in a Q study because the eigenvalue is not as important as the factor analysis. It is true that factors with a value of 1 or more have significance, but if the researcher judges that the eigenvalue is less than 1 , the factor can be extracted (Brown, 1980).

If factors are extracted, rotation is performed to maximize discrimination of factors. There are two types of rotation: judgmental and objective. Objective methods include Varimax, Quartimax, and Equimax. William Stephenson and Steven Brown recommend maximizing the degree of subjectivity arbitrarily. This is because Q methodology is based on the uncertainty principle of quantum mechanics. However, 
this approach is suitable for experienced researchers only, and therefore many researchers use Varimax, a deterministic rotation method, instead. The Varimax method calls for including as many research subjects as possible in the extracted factors. This method maximizes the variance difference between deterministic and specified factors. Thus, the difference in subjectivity between factors can be easily grasped (Kim, 2016, pp. 55-57). In this study, the factors were extracted by the centroid method and rotated by the Varimax method. Therefore, the extracted four types of recognition are comprehensive and differentiated. ${ }^{4}$

Table 4. Q-Sort Values of Factors for Each Statement

\begin{tabular}{|c|c|c|c|c|}
\hline Q Statement Number & Factor 1 & Factor 2 & Factor 3 & Factor 4 \\
\hline 1 & 0 & 4 & 0 & 4 \\
\hline 2 & 0 & 4 & 2 & 1 \\
\hline 3 & -2 & 1 & 3 & -1 \\
\hline 4 & -1 & 2 & -4 & -2 \\
\hline 5 & 0 & 2 & -3 & -1 \\
\hline 6 & 2 & 0 & -2 & -1 \\
\hline 7 & 1 & 1 & 4 & 2 \\
\hline 8 & -4 & -3 & -2 & -2 \\
\hline 9 & -3 & -3 & 0 & -3 \\
\hline 10 & 0 & -1 & -3 & -2 \\
\hline 11 & 3 & 2 & -1 & -1 \\
\hline 12 & -2 & -3 & -4 & 0 \\
\hline 13 & 0 & -2 & 0 & 0 \\
\hline 14 & -1 & -4 & -2 & 0 \\
\hline 15 & 2 & 0 & 3 & 0 \\
\hline 16 & 3 & -2 & -2 & 1 \\
\hline 17 & 2 & -1 & 0 & -4 \\
\hline 18 & 3 & 3 & 4 & -2 \\
\hline 19 & 4 & 1 & 2 & 1 \\
\hline 20 & 1 & 1 & 1 & 3 \\
\hline 21 & 1 & 0 & 0 & 3 \\
\hline 22 & 1 & 2 & 3 & 0 \\
\hline 23 & 4 & 3 & 1 & 4 \\
\hline 24 & -4 & -4 & -1 & -4 \\
\hline 25 & -1 & -1 & -3 & 0 \\
\hline
\end{tabular}

4. For a more detailed picture of the differences between the types of perception, see the table in the appendix that lists the descending array of differences between factors. 


\begin{tabular}{c|c|c|c|c}
\hline 26 & -2 & 0 & 1 & -3 \\
\hline 27 & 2 & 3 & 2 & 3 \\
\hline 28 & -2 & -1 & 0 & 2 \\
\hline 29 & -3 & 0 & 1 & 2 \\
\hline 30 & -1 & -2 & -1 & -3 \\
\hline 31 & 0 & 0 & 2 & 1 \\
\hline 32 & -3 & -2 & -1 & 2 \\
\hline eigenvalue & 9.57 & 2.80 & 2.06 & 1.75 \\
$\%$ var & 32 & 9 & 7 & 6 \\
\hline
\end{tabular}

Notes: * denotes a statistically significant factor loading ( $p$-value<0.05). +4 : strongly agree; -4 : strongly disagree; $0=$ neutral.

\section{Factors of Each Perception Pattern}

The primary characteristics of each of the four perception patterns in China are as follows. People in the factor 1 group stress the role of government intervention. A common feature of this group is the perception that software piracy is a problem a societal rather than personal problem. Moreover, since members of this group believe intellectual property rights must be protected, they maintain that increasing the manpower as well as the budget of the relevant organizations is necessary along with stricter punishment in the case of violation. The perception pattern of people in the factor 2 group is a normative, utility-focused one. They believe people use counterfeit software due to the high price of authorized products and owing to how easy it is to obtain and use pirated software. Like the people in the factor 1 group, this group believes that stricter enforcement and punishment will reduce unauthorized copying. People in the factor 3 group view the use of counterfeit software as a social problem and also believe that enforcement and punishment can reduce piracy. People in this group also view the quality of counterfeit software as good and see the initial distributor of pirated software as the problem rather than consumers. People in the factor 4 group believe, as do their South Korean counterparts, that the use of counterfeit software must be eradicated and that education and publicity, rather than punishment, are appropriate policy alternatives. The difference between the factor 4 group in Korea and the factor 4 group in China is that the latter believes people use pirated software because authorized products are unaffordable. 
Table 5. Perception Patterns

\begin{tabular}{c|l}
\hline Factor & Core Concept for Each Factor \\
\hline 1 & -normative legal model \\
\hline 2 & - economic utility model \\
\hline 3 & - punishment model \\
\hline 4 & - dual dilemma model (competing legal and cost perspective) \\
\hline
\end{tabular}

\section{Factor 1: Normative Legal Model}

The factor 1 group includes the most respondents as well as occupations, consisting of 10 respondents ( 5 students, 2 police officers, 1 researcher, 2 professors, and 1 office clerk). The factor 1 group was conceptualized as embracing a normative legal outlook that supports government intervention because the respondents assigned high factor scores to statements 19 ("To increase the likelihood of detection, the manpower, organization, and budget of the relevant enforcement bodies need to be beefed up") ( +4), 18 ("More stringent punishment will greatly reduce the use of pirated software") (+3), and 23 ("Intellectual property rights must be strictly protected, and doing so will result in enhanced quality of life") $(+4)$.

This factor also reflects the perspective of deterrence theory (statement 19, +4 , statement $18,+3)$. According to deterrence theory, the higher the certainty and severity of punishment, the less likely an individual will commit the crime. However, statement $9(-3)$ of this factor shows that there is a case where deterrence theory is not applied. This is because the people in the factor 1 group believe that the certainty of being punished for piracy alone will increase the use of authorized software. What this suggests is that the certainty and severity of punishment parts of deterrence theory should be judged separately. Respondents in these factor groups want the government to actively intervene in stamping out the use of illegal software. This is suggested by the -3 response to statement 32 ("People use illegal counterfeit software because the speed of development in the internet technology outpaces that of the cultural development; time will solve the problem"). People in this factor group think that illegal software use cannot be tackled by the current workforce (statement 19, +4 ) and that protecting intellectual property rights will enhance the quality of life (statement 23, +4 ). They also recognize that using illegal software is morally wrong and regard the use of illegal copies as a structural societal problem (statement 11, $+3)$. This view can also be seen in the acceptance of statement $16(+3)$, which specifies that the use of counterfeit software leads to the contraction of the relevant indus- 
try. Under the expected utility theory, individuals act to maximize their expected utility (Gopal \& Sanders, 1998; Gopal \& Sanders, 2000). According to the respondents in the factor 1 group, individuals are not only maximizing their expected utility when they act but are also reflecting a societal trend. Table 6 summarizes the primary statements for respondents in the factor 1 group.

Table 6. Key Statements of Factor 1

\begin{tabular}{|c|c|}
\hline $\begin{array}{l}\text { Q Factor } \\
\text { Score }\end{array}$ & Q Sample Statement \\
\hline \multirow{2}{*}{4} & $\begin{array}{l}\text { To increase the likelihood of detection, the manpower, organization, and budget } \\
\text { of the relevant enforcement bodies need to be beefed up (19). }\end{array}$ \\
\hline & $\begin{array}{l}2 \text { Intellectual property rights must be strictly protected, and doing so will result in } \\
\text { enhanced quality of life (23). }\end{array}$ \\
\hline \multirow{3}{*}{3} & $\begin{array}{l}1 \text { The reason why people use illegal copies of software is a social rather than } \\
\text { personal problem (11). }\end{array}$ \\
\hline & $\begin{array}{l}1 \text { Growing use of pirated software will contract the relevant industry, resulting in a } \\
\text { reduction in jobs (16). }\end{array}$ \\
\hline & 1 More stringent punishment will greatly reduce the use of pirated software (18). \\
\hline \multirow{3}{*}{-3} & $\begin{array}{l}9 \text { The certainty of being punished for software copyright violation will surely lead } \\
\text { to an increase in the use of licensed software products (9). }\end{array}$ \\
\hline & $\begin{array}{l}2 \text { Purchasing an authorized product seems to be a losing proposition, since the } \\
\text { products will be updated with newer versions soon after (29). }\end{array}$ \\
\hline & $\begin{array}{l}3 \text { People use of illegal counterfeit software because the speed of development in } \\
\text { the internet technology outpaces that of the cultural development; time will solve } \\
\text { the problem (32). }\end{array}$ \\
\hline \multirow[b]{2}{*}{-4} & 8 I buy illegal copies for a test run before purchasing authorized software (8). \\
\hline & $\begin{array}{l}2 \text { The use of counterfeit software is not pervasive throughout society but is rather } \\
\text { limited to a segment that includes youth (24). }\end{array}$ \\
\hline
\end{tabular}

Factor 2: Economic Utility Model

The factor 2 group reflects the economic utility model of a widespread use of pirated software. Factor 2 people say that the reason for using counterfeit goods is the high price of authorized goods and the convenience of purchasing them. For instance, 
as table 7 illustrates, respondents in this group believe that while "intellectual property rights must be strictly protected (statement $23,+3$ ) and "The replication and distribution of software without permission is unlawful and morally wrong" (statement 27 , +3 ), people still use pirated software because authorized products are expensive (statement 1), because it is easy to purchase of counterfeit products (statement 2), and because the punishment for software copyright violation is not severe (statement 18, +3 ). These views all reflect the expected utility theory, according to the which an individual seeks to choose an action that will maximize his or her expected utility by weighing costs and benefits of each alternative. Fear of being punished as well as concern over social criticism and not just economic interests are factors in assessing costs and benefits.

Factor 2 respondents share statements 8, 9, 18, 23, and 24 in common with factor 1 respondents. Like respondents in the factor 1 group, those in the factor 2 group think that intellectual property rights should be protected (statement $23,+3$ ). And they know that software piracy is not right (statement $27,+3$ ). However, the fact that the punishment is not severe (statement $18,+3$ ) and that illegal copies are cheaper and easy to access encourages piracy. Respondents in both the factor 1 and factor 2 groups also commonly regard illegal copying as a social structural problem (statement 24), but factor 2 respondents believe that individuals engage in illegal copying because of economic incentives, whereas factor 1 respondents believe that individuals engage in it because of lack of government control. Like factor 1 respondents, respondents in factor 2 also distinguish between the severity and certainty of punishment.

More clearly, factor 2 respondents show an active intention to use counterfeit software. They assign -3 to statement 8 that refers to purchasing illegal products for test purposes before purchasing the authorized product and to statement 12 that refers to using illegal products out of curiosity. In addition, they assign -4 to statement 14 that refers to the length of time it takes for authorized products to be distributed as well as to statement 24 that claims that the use of counterfeit products is not a problem in our society as a whole, which reveals their belief that they cannot be blamed for their personal use of counterfeit software. A total of 9 respondents including 1 police officer, 4 students, 1 researcher, 1 office clerk, 2 software company employees make up the factor 2 group. 
Table 7. Key Statements of Factor 2

\begin{tabular}{|c|c|}
\hline $\begin{array}{l}\text { Q Factor } \\
\text { Score }\end{array}$ & Q Sample Statement \\
\hline \multirow{2}{*}{4} & $\begin{array}{l}1 \text { I have no choice but to use illegal copies of software because the authorized } \\
\text { product is too expensive (1). }\end{array}$ \\
\hline & $\begin{array}{l}\text { It is more convenient to download illegal copies from the internet than to buy the } \\
\text { authorized product (2). }\end{array}$ \\
\hline \multirow{3}{*}{3} & 1 More stringent punishment will greatly reduce the use of pirated software (18). \\
\hline & $\begin{array}{l}\text { Intellectual property rights must be strictly protected, and doing so will result in } \\
\text { enhanced quality of life (23). }\end{array}$ \\
\hline & $\begin{array}{l}\text { The replication and distribution of software without permission is unlawful and } \\
\text { morally wrong (27). }\end{array}$ \\
\hline \multirow{3}{*}{-3} & $8 \mathrm{I}$ buy illegal copies for a test run before purchasing authorized software (8). \\
\hline & $\begin{array}{l}9 \text { The certainty of being punished for software copyright violation will surely lead } \\
\text { to an increase in the use of licensed software products (9). }\end{array}$ \\
\hline & 1 I use illegal copies just out of curiosity (12). \\
\hline \multirow{2}{*}{-4} & $\begin{array}{l}\text { I use counterfeit software because it takes too long for authorized products to be } \\
\text { distributed (14). }\end{array}$ \\
\hline & $\begin{array}{l}2 \text { The use of counterfeit software is not pervasive throughout society but is rather } \\
\text { limited to a segment that includes youth (24). }\end{array}$ \\
\hline
\end{tabular}

\section{Factor 3: Expected Punishment Model}

The respondents in the factor 3 group reflect a rational choice perspective on crime and believe that effective monitoring and harsh punishment can prevent the widespread use of illegal software. People in this factor group maintain that software piracy is prevalent it is hard to detect and because the punishment is not strict enough. The views of the respondents in the factor 3 group can be explained by deterrence theory. Deterrence theory compares the benefits of crime and the suffering from punishment. This theory suggests that as the certainty of severe and expeditious punishment increases, the incidence of crime decreases (Gibbs, 1975, p. 58). In line 
with deterrence theory, those in the factor 3 group recognize that the benefits of illegal software use outweigh the costs because the punishment is not severe and probability of detection is low. Respondents in this group also hold the original distributor more accountable than consumers who purchase the illegal product (statement 15, +3 ). It is possible that respondents in the factor 3 group assign responsibility to the original distributor of the illegal software as a self-rationalizing mechanism (Cho \& Lee, 2009). However, if there is no distributor, then there will be no illegal copy for individuals to purchase. Thus, preventing distributors from distributing illegal software should be a priority for enforcement.

As table 8 shows, respondents in this factor group see punishment as essential to protecting the ecosystem of the software industry. For instance, this factor group assigned +4 to statement 18 that refers to how harsher punishment will greatly reduce the use of counterfeit products as well as to statement 7 that refers to the role of improved detection of software piracy in increasing the purchase of authorized products. Respondents in this group also assigned +3 the statement 11 that describes the use of counterfeit software as a social structural issue. On the other hand, the group gave -3 to statement 10 that refers to using illegal software only because others around them happen to be using them. Respondents in this group thus can be said to be making an active choice use to use counterfeit products rather than simply passively following what others around them are doing. In dismissing the idea that illegal software users are merely passively following what others are doing, respondents in group can be said to reject basic tenets of positive general prevention theory, which maintains that influence of an individual's environment is paramount when it comes to crime. According to the respondents in the factor 3 group, people commit illegal acts irrespective of their surroundings and so interaction with law-abiding friends, colleagues, and parents will not necessarily prevent an individual from engaging in crime. Table 8 shows the key statements for the factor 3 group. The factor 3 group is made up of four respondents: two students, one civil servant and one office worker. This group, similar to factor 1 group, gives high factor scores to ease of detection and strictness of punishment; it also agrees on the matter of cost with the factor 2 group. 
Table 8. Key Statements of Factor 3

\begin{tabular}{|c|c|}
\hline $\begin{array}{l}\text { Q Factor } \\
\text { Score }\end{array}$ & Q Sample Statements \\
\hline \multirow{2}{*}{4} & $\begin{array}{l}\text { Improved detection of counterfeit software will lead to an increase in the purchase } \\
\text { of authorized software products (7). }\end{array}$ \\
\hline & More stringent punishment will greatly reduce the use of pirated software (18). \\
\hline \multirow{3}{*}{3} & $\begin{array}{l}3 \text { The quality of counterfeit software is almost equal to that of authorized software } \\
\text { (3). }\end{array}$ \\
\hline & $\begin{array}{l}\text { When it comes to software piracy, the fault of the first distributor of the pirated } \\
\text { copy is greater than that of downloaders (15). }\end{array}$ \\
\hline & $\begin{array}{l}\text { The reason why people use illegal copies of software is a social rather than } \\
\text { personal problem (11). }\end{array}$ \\
\hline \multirow{3}{*}{-3} & $\begin{array}{l}5 \text { The use of pirated software is common and is not limited to particular individuals } \\
\text { (5). }\end{array}$ \\
\hline & $\begin{array}{l}\text { It is unfair that I should have to use authorized products while others use } \\
\text { counterfeit products (10). }\end{array}$ \\
\hline & $\begin{array}{l}\text { The press exaggerates about the use of illegal copies of software, and people } \\
\text { overestimate the graveness of the problem (25). }\end{array}$ \\
\hline-4 & $\begin{array}{l}\text { Although I can afford to purchase licensed software, I would rather spend the } \\
\text { money on somewhere else (4). } \\
\text { I use illegal copies just out of curiosity (12). }\end{array}$ \\
\hline
\end{tabular}

\section{Factor 4: Norm-Centered Perception Pattern}

Respondents in the factor 4 group illustrate the dilemma of being both a rational consumer and a moral citizen, as they simultaneously support two competing statements. A total of three respondents belong to this group: one researcher and two software company employees. The representative statements for the factor 4 group are shown in table 9. Factor 4 respondents emphasize social norms because they consider using authorized software a duty. This group assigned +4 to statement 23 that refers to strictly protecting intellectual property rights on the grounds that the protection of these rights enhances the quality of life and +3 to statement 27 that 
refers to the making and distributing of pirated software as unlawful and morally wrong, which reveals their perception that using authorized software products is not only conducive to the individual pursuit of happiness and the prosperity of the state but also the legally and morally appropriate action. Acceptance of these statements reflects positive general prevention theory. While deterrence theory (negative general prevention theory) maintains that crime is prevented through the threat of punishment, positive general prevention theory maintains that crime is prevented by changing people's consciousness via education (Hong, 2015). Factor 4 respondents used counterfeit software because of the high price of authorized goods (statement $1,+4)$. However, the respondents in this group, unlike those in the factor 3 group, believe that persuasion through education and publicity will be more effective in reducing the use of illegal software than harsher punishment (statement $20,+3$ ).

In addition, factor 4 respondents view the cloned product as inferior to the authorized product (statement $21,+3$ ) but use it nevertheless because the authorized product is too expensive (statement $1,+4$ ). That respondents in this factor group are influenced by price point, can be seen in their assigning -4 points to statement 17 ("No matter how expensive, we must use authorized products instead of pirated software"). For the respondents in this group, then, the solution to illegal software use would be a policy whereby it was required that authorized products be reasonably priced. Respondents in the factor 4 group also regard the use of counterfeit products as a structural problem of society (statements $24,-4$ ). All four factor groups agree on this point.

In addition, this group believes that the certainty of punishment will not increase the use of authorized products (statement 9, -3) and that civic education and public campaigns will be more effective than enforcement and punishment in encouraging the use of authorized products (statement $20,+3$ ). Thus respondents in this group deny the premise of deterrence theory, namely, that the certainty of punishment and the strictness of punishment will reduce crime. 
Table 9. Key Statements of Factor 4

\begin{tabular}{|c|c|}
\hline $\begin{array}{l}\text { Q Factor } \\
\text { score }\end{array}$ & Q Sample Statement \\
\hline \multirow{2}{*}{4} & $\begin{array}{l}\text { I have no choice but to use illegal copies of software because the authorized } \\
\text { product is too expensive (1). }\end{array}$ \\
\hline & $\begin{array}{l}\text { Intellectual property rights must be strictly protected, and doing so will result in } \\
\text { enhanced quality of life (23). }\end{array}$ \\
\hline \multirow{3}{*}{3} & $\begin{array}{l}\text { In order to establish the use of authorized products as a cultural norm, persuasion } \\
\text { and understanding through education and publicity must be prioritized over legal } \\
\text { enforcement and punishment (20). }\end{array}$ \\
\hline & $\begin{array}{l}\text { I try to use authorized products whenever I can because using pirated software } \\
\text { often causes unnecessary inconveniences (21). }\end{array}$ \\
\hline & $\begin{array}{l}\text { The replication and distribution of software without permission is unlawful and } \\
\text { morally wrong (27). }\end{array}$ \\
\hline \multirow{3}{*}{-3} & $\begin{array}{l}\text { The certainty of being punished for software copyright violation will surely lead to } \\
\text { an increase in the use of licensed software products (9). }\end{array}$ \\
\hline & $\begin{array}{l}\text { Using illegal copies is different from stealing; I don't feel guilty when I use } \\
\text { counterfeit software (26). }\end{array}$ \\
\hline & $\begin{array}{l}\text { Authorized products are overpriced compared to their development cost, so using } \\
\text { authorized products promotes economic inequality (30). }\end{array}$ \\
\hline \multirow{2}{*}{-4} & $\begin{array}{l}\text { No matter how expensive, we must use authorized products instead of pirated } \\
\text { software (17). }\end{array}$ \\
\hline & $\begin{array}{l}\text { The use of counterfeit software is not pervasive throughout society but is rather } \\
\text { limited to a segment that includes youth (24). }\end{array}$ \\
\hline
\end{tabular}

\section{Correlation between Factors}

Table 10 shows that the highest correlation coefficient is between factor 1 and factor 2 at 0.5055 while the lowest is between factor 3 and factor 4 at 0.1909 .5 The cor-

5. In general, if the correlation between factors is high, it can be said that the number of factors is excessively extracted. In this case, reextraction of the factors is required (Kim, 2016). For this reason, this study also examined all the correlations for three, four, and five factors. In the case of four factors, the correlation was relatively low. These results are also consistent with those of the four perspectives when conducting the preinterview. See the appendix for the correlation tables. 
relation between factor 1 and factor 2 exceeds 0.5 because factor 1 and factor 2 have common statements $8(-4,-3), 9(-3,-3), 18(+3,+3), 23(+4,+3) 4,-4)$. Statements 18 $(+3,+3)$ and $23(+4,+3)$ received higher scores among the statements that factor 1 and 2 have in common. Both factor groups agree that intellectual property rights need to be protected $(23,+4,+3)$ and that punishment must be more severe than it is now to reduce the use of counterfeit products $(18,+3,+3)$. In addition, respondents in these two factor groups oppose statements $8(-4,-3), 9(-3,-3)$, and $24(-4,-4)$ and strongly oppose statement $24(-4,-4)$. This suggests that both regard the use of counterfeit products as a social issue. It can also be assumed that their opposition to statement $8(-4,-3)$ means they buy only authorized software. There are differences between the two groups, however. Statement $19(+4)$, which reflects the viewpoint of deterrence theory, is commonly supported by factor 1 respondents, whereas statements $1(+4)$ and $2(+4)$, which reflect the viewpoint of expected utility theory, are commonly supported by factor 2 respondents. Therefore, it is necessary to divide these respondents into two separate factor groups. The correlation coefficients between factor 2 and factor 3 and between factor 2 and factor 4 are over 0.4 , indicating that there are also many mutually supported statements among respondents in these factor groups.

Table 10. Correlation between Factors

\begin{tabular}{c|c|c|c|c}
\hline Classification & Factor 1 & Factor 2 & Factor 3 & Factor 4 \\
\hline Factor 1 & 1.0000 & 0.5055 & 0.3636 & 0.3193 \\
\hline Factor 2 & & 1.0000 & 0.4237 & 0.4190 \\
\hline Factor 3 & & & 1.0000 & 0.1909 \\
\hline Factor 4 & & & & 1.0000 \\
\hline
\end{tabular}

\section{Synthesis of Analysis Results}

The purpose of this study is to analyze why Chinese consumers use illegal software and how they think about this from the Q-methodological perspective. We found four different patterns of perception. The first reflects a normative legal response, the second an economic utility argument, the third a deterrence argument, and the fourth a dilemma that is caused by the consumer having to choose between the cheapness of illegal software and its illegality. The perceptions of the respondents in the factor 1 and factor 3 groups can be explained by deterrence theory. However, 
the mechanism of action is different for the respondents in each group. Both groups think that weak penalties and loose enforcement make the use of illegal software more attractive. However, the factor 1 group supports the expansion of enforcement bodies, while the factor 3 group advocates harsher punishment. The perceptions of the respondents in the factor 2 group can be explained by expected utility theory. On this view, consumers purchase illegal software because it is cheap and because there are weak penalties for doing so. The government can address this problem by setting a market price for authorized products and by levying harsher penalties. The perceptions of the respondents in the factor 4 group can be explained by positive general prevention theory. Consumers, on this view, believe that piracy is immoral but purchase illegal software nevertheless because of the high price of the authorized product. Setting a market price for authorized products as well as persuading consumers through education and publicity to not buy illegal products are the solutions to the problem for respondents in the factor 4 group. Table 11 summarizes these findings.

Table 11. Applied Theory and Causality for Each Factor

\begin{tabular}{l|l|l|l|l}
\hline Classification & Model Name & $\begin{array}{c}\text { Application } \\
\text { Theory }\end{array}$ & $\begin{array}{c}\text { Operating } \\
\text { Mechanism }\end{array}$ & Policy Tools \\
\hline Factor 1 & $\begin{array}{l}\text { Normative legal } \\
\text { model }\end{array}$ & deterrence theory & $\begin{array}{l}\text { weak punishment } \\
\text { and loose control }\end{array}$ & $\begin{array}{l}\text { expansion of } \\
\text { manpower; } \\
\text { expansion of } \\
\text { budget }\end{array}$ \\
\hline Factor 2 & $\begin{array}{l}\text { Economic utility } \\
\text { model }\end{array}$ & $\begin{array}{l}\text { expected utility } \\
\text { theory }\end{array}$ & $\begin{array}{l}\text { low penalty level } \\
\text { and lower price } \\
\text { and convenience of } \\
\text { replicas }\end{array}$ & $\begin{array}{l}\text { market control; } \\
\text { harsher } \\
\text { punishment }\end{array}$ \\
\hline Factor 3 & $\begin{array}{l}\text { Expected } \\
\text { punishment } \\
\text { model }\end{array}$ & deterrence theory & $\begin{array}{l}\text { weak penalty and } \\
\text { low probability of } \\
\text { detection }\end{array}$ & $\begin{array}{l}\text { strengthening of } \\
\text { legal regulations; } \\
\text { harsher } \\
\text { punishment }\end{array}$ \\
\hline Factor 4 & $\begin{array}{l}\text { Norm-Centered } \\
\text { Perception } \\
\text { Pattern }\end{array}$ & $\begin{array}{l}\text { positive general } \\
\text { prevention theory }\end{array}$ & $\begin{array}{l}\text { high prices of } \\
\text { authorized goods }\end{array}$ & $\begin{array}{l}\text { market control; } \\
\text { education / } \\
\text { publicity }\end{array}$ \\
\hline
\end{tabular}


Table 12. Shows the statements the respondents in the four factor groups hold in common. This finding suggests that Chinese consumers believe that enforcement bodies ought to make eliminating the use of pirated software a priority and that those who use illegal products should be harshly punished. However, Chinese consumers also believe that illegal use is common due to the cost of authorized products. Chinese consumers are thus confronted with dilemma. Other perceptions shared by respondents in all four factor groups are that illegal copying and distribution of software is against the law, that intelligence property rights must be protected, and that in order to crack down on the use of illegal copies, enforcement bodies need more manpower and larger budgets.

Table 12. Common Statements

\begin{tabular}{|c|c|c|c|c|c|}
\hline $\begin{array}{c}\text { Q } \\
\text { Statement } \\
\text { Number }\end{array}$ & Sample Statement & F1 & F2 & F3 & F4 \\
\hline 7 & $\begin{array}{l}\text { Improved detection of counterfeit software will increase } \\
\text { the purchase of authorized software. }\end{array}$ & 1 & 1 & 4 & 2 \\
\hline 8 & $\begin{array}{l}\text { I buy illegal copies for a test run before buying } \\
\text { authorized products rather than for using it. }\end{array}$ & -4 & -3 & -2 & -2 \\
\hline 19 & $\begin{array}{l}\text { To increase the likelihood of detection, the manpower, } \\
\text { organization, and budget of the relevant enforcement } \\
\text { bodies need to be beefed up. }\end{array}$ & 4 & 1 & 2 & 1 \\
\hline 20 & $\begin{array}{l}\text { In order to establish the use of authorized products as } \\
\text { a cultural norm, persuasion and understanding through } \\
\text { education and publicity must be prioritized over legal } \\
\text { enforcement and punishment. }\end{array}$ & 1 & 1 & 1 & 3 \\
\hline 23 & $\begin{array}{l}\text { Intellectual property rights must be strictly protected, and } \\
\text { doing so will result in enhanced quality of life. }\end{array}$ & 4 & 3 & 1 & 4 \\
\hline 24 & $\begin{array}{l}\text { The use of counterfeit software is not pervasive } \\
\text { throughout society but rather is limited to a segment that } \\
\text { includes youth. }\end{array}$ & -4 & -4 & -1 & -4 \\
\hline 27 & $\begin{array}{l}\text { The replication and distribution of software without } \\
\text { permission is unlawful and morally wrong. }\end{array}$ & 2 & 3 & 2 & 3 \\
\hline 30 & $\begin{array}{l}\text { Authorized products are overpriced compared to their } \\
\text { development costs, so using authorized products } \\
\text { promotes economic inequality. }\end{array}$ & -1 & -2 & -1 & -3 \\
\hline
\end{tabular}




\section{CONCLUSION AND IMPLICATIONS}

In this paper, we have analyzed the subjective perceptions of Chinese respondents on the use of counterfeit software by applying $\mathrm{Q}$ methodology and derived four different perception patterns on illegal software use. These four perception patterns illustrate objective forms of the subjective world of the research subjects. Chinese consumers understand that software piracy is illegal but believe that illegal use is widespread due to economic utility and that the use of illegal copies is a structural problem of society. This may be a self-rationalization mechanism (Cho \& Lee, 2009), but on the other hand, it also reflects the reality that illegal software use is rampant. A further implication is that those in the factor 1 and factor 3 groups believe that the practice of illegal copying is rampant due to a lack of manpower and insufficient budgets in organizations charged with regulating the software and due to lack of enforcement and punishment. These perceptions suggest that the Chinese government should intervene more heavily in the future and increase the level of enforcement and punishment (which is consistent with a recent finding that price factors are no longer a key determinant in software piracy in China [Lin, 2015]). All of these perspectives recognize that piracy is a structural issue and that continuous and consistent enforcement and stricter punishment are necessary to address it.

From a policy perspective, this study suggests that there are four different perception patterns regarding software piracy, which suggests that policies can be fine-tuned based on different subjective perceptions (Kim, Lee, and Kim, 2015). For example, respondents in the factor 1 and factor 3 groups feel that the punishment for illegal software use needs to be more severe. Although both groups do consider price to be a factor, they agree that piracy will be reduced if the punishment is made stricter.

Respondents in the factor 3 group regard the original distributor of pirated software is a larger problem than the use of an illegal copy by a consumer (statement 15, +3 ). and that therefore, it is critical to eliminate distributors. Factor 2 and factor 4 respondents think that the high price of authorized goods is a problem and that in order to increase the use of authorized software, it is necessary to implement a policy whereby authorized products are reasonably priced. The government can make a policy to stabilize prices through price competition among suppliers.

Although this study has yielded significant findings, it has limitations. For one, it does not include teenagers in the P sample. For another, the difference between the public and private sectors when it comes to illegal copying cannot be accounted for solely by reference to the fact that private companies were the last to be required by the central government to ensure that authorized software was being used by their employees, and a follow-up study is thus needed. In addition, the significance of this 
study is limited in that the views of respondents are subjective opinions and that the research subjects were not been able to disclose in detail the way in which illegal copying is carried out. Put simply, the Q methodology can generate hypotheses but cannot verify them. This study thus needs be supplemented by subsequent studies.

Piracy still poses a serious challenge in China, and a macro policy is needed to solve the problem. The patterns of perceptions found in both China and Korea suggest that it is necessary to make punishment more severe and to strengthen enforcement so that those involved in software piracy pay for their wrongdoing. However, enforcement and punishment alone will not resolve the issue; they must be coupled with an understanding of market principles, education, and a raising of public awareness about value of intellectual property rights.

\section{REFERENCES}

Andrés, A. R., \& Asongu, S. A. 2013. Fighting software piracy: Which governance tools matter for Africa? Journal of Business Ethics, 118 (3), 667-682.

Asongu, S. A., Singh, P., \& Le Roux, S. 2016. Fighting software piracy: Some global conditional policy instruments. Journal of Business Ethics, 1-15: https://doi. org/10.1007/s10551-016-3291-7.

Brown, S. R. 1980. Political subjectivity: Applications of $Q$ methodology in political science. New Haven, CT: Yale University Press.

Brown, S. R., \& Ungs, T. D. 1970. Representativeness and the study of political behavior: An application of Q technique to reactions to the Kent State incident. Social Science Quarterly, 51(3): 514-526.

Brown, S. R., Durning, D. W., \& Selden, S. 1999. Q methodology. Public Administration and Public Policy, 71: 599-638.

Business Software Alliance. 2014. Korea's lowest rate of illegal software usage (38\%). Press release, June 24.

Cho, Y. O., \& Lee, M. J. 2009. Sexual deviance and the self-rationalization of sex offenders. Korea Public Security Administration 18 (1): 333-362.

Choi, E. J., \& Kim, K. Y. 2009. The effectiveness of online digital piracy control on curbing piracy. Quarterly Copyright, (22): 25-49.

Douglas, D. E., Cronan, T. P., \& Behel, J. D. 2007. Equity perceptions as a deterrent to software piracy behavior. Information and Management, 44(5): 503-512.

Driouchi, A., Wang, M., \& Driouchi, T. 2015. Determinants of software piracy under risk aversion: A model with empirical evidence. European Journal of Informa- 
tion Systems, 24(5): 519-530.

Korean Association for ITC Development and Korea Energy Association. 2014. ICT survey.

Gartner. 2015. Gartner market databook. Second quarter update.

Gibbs, J. P. 1975. Crime, punishment, and deterrence. New York: Elsevier.

Gopal, R. D., \& Sanders, G. L. 1998. International software piracy: Analysis of key issues and impacts. Information Systems Research, 9(4): 380-397.

Gopal, R. D., \& Sanders, G. L. 2000. Global software piracy: You can't get blood out of a turnip. Communications of the ACM, 43(9): 82-89.

Higgins, G. E., Wilson, A. L., \& Fell, B. D. 2005. An application of deterrence theory to software piracy. Journal of Criminal Justice and Popular Culture, 12(3): 166-184.

Hong, Y. K. (2015). Strengthening the norms of trust through punishment. Law of Korea, 77: 301-356.

INSEAD. 2013. Competitive advantage: The economic impact of properly licensed software.

Jin, H. Y. 2015. The status of the software industry. Information and Communication Policy Institute, Focus, 27 (15), 2015.

Jo, U. S. 2010. How individual users and PC sellers perceive the illegal use of software. MA thesis, Chonnam National University.

Kang, H. Y., et al. 2012. Smart ecosystem diffusion and the software industry paradigm shift. Korea Information Society Development Institute.

Kerlinger, F. N. 1973. Foundations of behavioral research (2nd ed). New York: Holt, Rinehart, and Winston.

Kim, H. G. 2008. Q methodology: Science, philosophy, theory, analysis and application. Seoul: Communication Books.

Kim, J. O., \& Kim, C. S. 2008. Paradox of gambling games and overregulation. Local Government Studies, 12 (2): 201-227.

Kim, K. Y. 2004. Software piracy in ethical decision making. Information Policy, 11 (4): 48-86.

Kim, S. E. 2007. Q methodology and social science. Busan: Geumjeong.

Kim, S. E. 2016. Q methodology and social science. Seoul: Jomyongmunwhasa.

Kim, C. W., \& Jung, K. H. 2016. Analysis of types of perception of illegal software use. Korean Society and Administration Research, 26 (4): 219-244.

Kim, C. W., Lee, J. W., \& Kim, S. E. 2015. Analysis of types of perception of problems and government countermeasures 3.0. Korean Society and Administration Research, 26 (2): 197-218.

Korea Copyright Committee. 2015. Software administration guide. 
Korea Information Technology Agency. 2014. ICT issues weekly. August 29, 2014. Korea Trade Promotion Corporation. 2014. 2014 China regional entry strategy report. Lee, S. W. (2011). Factors that interfere with the Intention to Use authorized general purpose office software in small and medium-sized enterprises. $\mathrm{PhD}$ diss., Konkuk University.

Lee, S. H., \& Yoo, B. (2009). A review of the determinants of counterfeiting and piracy and the proposition for future research. Korean Journal of Policy Studies, 24 (1): $1-38$.

Lin, X. D., Cheng, L. 2015. Influence Factors for Software Privacy in China: An integrated model analysis framework. Journal of Shenzhen University (June): 86-92.

Moores, T., \& Dhillon, G. 2000. Software piracy: A view from Hong Kong. Communications of the ACM, 43(12): 88-93.

Nill, Alexander, and Schibrowsky, John. 2010. Factors that influence software piracy: A view from Germany." Communications of the ACM, 53(6): 131-134.

Park, S. K., Son, D. K., \& Lee, S. R. 2001. Criminal policy. Seoul: Korea Criminal Policy Institute.

Sabatier, Paul A., \& Mazmanian, D. 1979. The conditions of effective implementation: A guide to accomplishing policy objectives. Policy Analysis, 5: 481-504.

Son, H. K. 2012. Status of efforts to ensure use of authorized software in China. Korea Copyright Commission, Copyright Trend No. 16.

Song, S. J. 2002. Bandura's theory of moral development. Moral Education Research, 3: $85-109$.

Stephenson, W. 1953. The study of behavior: Q-technique and its methodology. Chicago: University of Chicago Press.

Yoo, C.-W., Sanders, G. L., Rhee, C., \& Choe, Y.-C. 2011. The effect of deterrence policy in software piracy. Information and Development, 30(4): 342-357.

Yoo, C. W., Kim, M. S., \& Choi, Y. Chan. 2008. Illegal software use in Vietnam. E-Business Research, 9 (1): 237-258.

Yoon, Y. K. 2004. Prevention of crime through normative learning: Based on a survey of norms of high school students. Comparative Criminal Justice Research, 6 (2): 285-312.

Yunhap News. 2016. Chinese imports shrink but dependence on exports continues to grow. May 5. 


\section{APPENDIX}

Correlation between 3 Factors

\begin{tabular}{|c|c|c|c|c|c|}
\hline Classificatior & \multicolumn{2}{|c|}{ Factor 1} & \multicolumn{2}{|c|}{ Factor 2} & Factor 3 \\
\hline Factor 1 & \multicolumn{2}{|c|}{1.0000} & \multicolumn{2}{|c|}{0.5718} & 0.6128 \\
\hline Factor 2 & & & \multicolumn{2}{|c|}{1.0000} & 0.3877 \\
\hline Factor 4 & & & & & 1.0000 \\
\hline \multicolumn{6}{|c|}{ Correlation between 4 Factors } \\
\hline Classification & Factor 1 & \multicolumn{2}{|c|}{ Factor 2} & Factor 3 & Factor 4 \\
\hline Factor 1 & 1.0000 & \multicolumn{2}{|c|}{0.5055} & 0.3636 & 0.3193 \\
\hline Factor 2 & & \multicolumn{2}{|c|}{1.0000} & 0.4237 & 0.4190 \\
\hline Factor 3 & & & \multicolumn{2}{|c|}{1.0000} & 0.1909 \\
\hline Factor 4 & & & & & 1.0000 \\
\hline \multicolumn{6}{|c|}{ Correlation between 5 Factors } \\
\hline Classification & Factor 1 & Factor 2 & Factor 3 & Factor 4 & Factor 5 \\
\hline Factor 1 & 1.0000 & 0.3371 & 0.4638 & 0.4868 & 0.5306 \\
\hline Factor 2 & & 1.0000 & 0.3670 & 0.4013 & 0.1986 \\
\hline Factor 3 & & & 1.0000 & 0.3013 & 0.3095 \\
\hline Factor 4 & & & & 1.0000 & 0.4224 \\
\hline Factor 5 & & & & & 1.0000 \\
\hline
\end{tabular}

\begin{tabular}{c|c|c|c|c|c|c|c}
\hline \multicolumn{3}{c}{\begin{tabular}{c} 
Descending Array \\
\multicolumn{2}{c}{ of Differences between F1 and 2 }
\end{tabular}} & \multicolumn{4}{c}{$\begin{array}{c}\text { Descending Array } \\
\text { of Differences between F 1 and 3 }\end{array}$} \\
\hline Number & Type & $\mathbf{1}$ Type & $\begin{array}{c}\mathbf{2} \\
\text { Difference }\end{array}$ & No. & Type & 1 Type & $\begin{array}{c}\text { 3 } \\
\text { Difference }\end{array}$ \\
\hline 16 & 1.237 & -0.685 & 1.922 & 16 & 1.237 & -0.797 & 2.034 \\
\hline 15 & 1.177 & -0.099 & 1.276 & 11 & 1.281 & -0.681 & 1.961 \\
\hline 6 & 1.017 & -0.181 & 1.198 & 6 & 1.017 & -0.796 & 1.813 \\
\hline 17 & 0.915 & -0.265 & 1.180 & 23 & 1.546 & 0.266 & 1.280 \\
\hline 19 & 1.657 & 0.510 & 1.147 & $10 j$ & -0.160 & -1.378 & 1.218 \\
\hline 14 & -0.524 & -1.569 & 1.046 & 5 & -0.152 & -1.366 & 1.213 \\
\hline 21 & 0.890 & -0.018 & 0.908 & 21 & 0.890 & -0.149 & 1.039 \\
\hline 13 & -0.087 & -0.862 & 0.776 & 4 & -0.447 & -1.404 & 0.957 \\
\hline 11 & 1.281 & 0.628 & 0.653 & 12 & -0.813 & -1.550 & 0.737 \\
\hline 30 & -0.430 & -1.027 & 0.597 & 17 & 0.915 & 0.243 & 0.672 \\
\hline 121 & -0.813 & -1.335 & 0.521 & 19 & 1.657 & 1.036 & 0.622 \\
\hline 23 & 1.546 & 1.255 & 0.292 & 14 & -0.524 & -0.992 & 0.468 \\
\hline
\end{tabular}




\begin{tabular}{|c|c|c|c|c|c|c|c|}
\hline \multicolumn{4}{|c|}{$\begin{array}{c}\text { Descending Array } \\
\text { of Differences between F1 and } 2\end{array}$} & \multicolumn{4}{|c|}{$\begin{array}{c}\text { Descending Array } \\
\text { of Differences between F } 1 \text { and } 3\end{array}$} \\
\hline Number & Type & 1 Type & $\begin{array}{c}2 \\
\text { Difference }\end{array}$ & No. & Type & 1 Type & $\begin{array}{c}3 \\
\text { Difference }\end{array}$ \\
\hline 7 & 0.535 & 0.291 & 0.243 & 25 & -0.805 & -1.247 & 0.442 \\
\hline 24 & -1.992 & -2.161 & 0.169 & 20 & 0.424 & 0.355 & 0.070 \\
\hline $10 \mathrm{j}$ & -0.160 & -0.255 & 0.095 & 13 & -0.087 & -0.096 & 0.009 \\
\hline 20 & 0.424 & 0.351 & 0.073 & 27 & 1.149 & 1.210 & -0.061 \\
\hline 31 & -0.146 & -0.201 & 0.055 & 1 & -0.156 & -0.052 & -0.104 \\
\hline 8 & -1.280 & -1.329 & 0.049 & 30 & -0.430 & -0.307 & -0.123 \\
\hline 9 & -1.197 & -1.193 & -0.004 & 8 & -1.280 & -1.124 & -0.156 \\
\hline $18 r$ & 1.275 & 1.291 & -0.016 & $18 r$ & 1.275 & 1.658 & -0.383 \\
\hline 22 & 0.658 & 0.726 & -0.068 & 15 & 1.177 & 1.587 & -0.410 \\
\hline 27 & 1.149 & 1.503 & -0.354 & 32 & -1.234 & -0.633 & -0.602 \\
\hline 25 & -0.805 & -0.422 & -0.383 & 31 & -0.146 & 0.589 & -0.735 \\
\hline 28 & -0.934 & -0.495 & -0.439 & 22 & 0.658 & 1.430 & -0.771 \\
\hline 32 & -1.234 & -0.613 & -0.621 & 28 & -0.934 & -0.120 & -0.814 \\
\hline 5 & -0.152 & 0.709 & -0.861 & 2 & -0.335 & 0.722 & -1.057 \\
\hline 26 & -0.864 & 0.191 & -1.055 & 26 & -0.864 & 0.282 & -1.146 \\
\hline 29 & -1.107 & 0.179 & -1.286 & 7 & 0.535 & 1.710 & -1.176 \\
\hline 3 & -1.098 & 0.249 & -1.347 & $9 i$ & -1.197 & 0.126 & -1.323 \\
\hline 4 & -0.447 & 1.147 & -1.594 & 29 & -1.107 & 0.305 & -1.412 \\
\hline 1 & -0.156 & 1.865 & -2.022 & 24 & -1.992 & -0.415 & -1.577 \\
\hline 2 & -0.335 & 1.814 & -2.149 & 3 & -1.098 & 1.589 & -2.687 \\
\hline \multicolumn{4}{|c|}{$\begin{array}{c}\text { Descending Array } \\
\text { of Differences between F1 and } 4\end{array}$} & \multicolumn{4}{|c|}{$\begin{array}{c}\text { Descending Array } \\
\text { of Differences between F2 and } 3\end{array}$} \\
\hline No. & Type & 1 Type & $\begin{array}{c}4 \\
\text { Difference }\end{array}$ & No. & Type & 2 Type & $\begin{array}{c}3 \\
\text { Difference }\end{array}$ \\
\hline 17 & 0.915 & -1.547 & 2.462 & 4 & 1.147 & -1.404 & 2.552 \\
\hline 18 & 1.275 & -0.985 & 2.261 & 5 & 0.709 & -1.366 & 2.074 \\
\hline 11 & 1.281 & -0.444 & 1.724 & 1 & 1.865 & -0.052 & 1.918 \\
\hline 15 & 1.177 & -0.340 & 1.516 & 11 & 0.628 & -0.681 & 1.309 \\
\hline 6 & 1.017 & -0.459 & 1.476 & 10 & -0.255 & -1.378 & 1.123 \\
\hline 19 & 1.657 & 0.320 & 1.337 & 2 & 1.814 & 0.722 & 1.092 \\
\hline 22 & 0.658 & -0.175 & 0.834 & 23 & 1.255 & 0.266 & 0.989 \\
\hline 16 & 1.237 & 0.442 & 0.796 & 25 & -0.422 & -1.247 & 0.825 \\
\hline 10 & -0.160 & -0.951 & 0.791 & 6 & -0.181 & -0.796 & 0.616 \\
\hline 30 & -0.430 & -1.049 & 0.619 & 27 & 1.503 & 1.210 & 0.293 \\
\hline 5 & -0.152 & -0.561 & 0.409 & 12 & -1.335 & -1.550 & 0.215 \\
\hline 4 & -0.447 & -0.729 & 0.282 & 21 & -0.018 & -0.149 & 0.131 \\
\hline
\end{tabular}




\begin{tabular}{|c|c|c|c|c|c|c|c|}
\hline \multicolumn{4}{|c|}{$\begin{array}{c}\text { Descending Array } \\
\text { of Differences between F1 and } 2\end{array}$} & \multicolumn{4}{|c|}{$\begin{array}{c}\text { Descending Array } \\
\text { of Differences between F } 1 \text { and } 3\end{array}$} \\
\hline Number & Type & 1 Type & $\begin{array}{c}2 \\
\text { Difference }\end{array}$ & No. & Type & 1 Type & $\begin{array}{c}3 \\
\text { Difference }\end{array}$ \\
\hline 26 & -0.864 & -1.103 & 0.239 & 16 & -0.685 & -0.797 & 0.112 \\
\hline 13 & -0.087 & -0.218 & 0.131 & 32 & -0.613 & -0.633 & 0.020 \\
\hline 9 & -1.197 & -1.157 & -0.040 & 20 & 0.351 & 0.355 & -0.004 \\
\hline 27 & 1.149 & 1.273 & -0.124 & 26 & 0.191 & 0.282 & -0.091 \\
\hline 24 & -1.992 & -1.662 & -0.330 & 29 & 0.179 & 0.305 & -0.126 \\
\hline 8 & -1.280 & -0.949 & -0.331 & 8 & -1.329 & -1.124 & -0.205 \\
\hline 3 & -1.098 & -0.677 & -0.421 & 18 & 1.291 & 1.658 & -0.367 \\
\hline 31 & -0.146 & 0.388 & -0.534 & 28 & -0.495 & -0.120 & -0.375 \\
\hline 14 & -0.524 & 0.056 & -0.580 & 17 & -0.265 & 0.243 & -0.507 \\
\hline 7 & 0.535 & 1.123 & -0.588 & 19 & 0.510 & 1.036 & -0.526 \\
\hline 2 & -0.335 & 0.284 & -0.619 & 14 & -1.569 & -0.992 & -0.578 \\
\hline 23 & 1.546 & 2.224 & -0.678 & 22 & 0.726 & 1.430 & -0.704 \\
\hline 25 & -0.805 & -0.104 & -0.701 & 30 & -1.027 & -0.307 & -0.719 \\
\hline 21 & 0.890 & 1.597 & -0.706 & 13 & -0.862 & -0.096 & -0.767 \\
\hline 12 & -0.813 & -0.102 & -0.711 & 31 & -0.201 & 0.589 & -0.790 \\
\hline 20 & 0.424 & 1.327 & -0.903 & 9 & -1.193 & 0.126 & -1.319 \\
\hline 28 & -0.934 & 0.833 & -1.767 & 3 & 0.249 & 1.589 & -1.340 \\
\hline 1 & -0.156 & 1.614 & -1.771 & 7 & 0.291 & 1.710 & -1.419 \\
\hline 29 & -1.107 & 0.781 & -1.888 & 15 & -0.099 & 1.587 & -1.686 \\
\hline 2 & -0.335 & 1.814 & -2.149 & 24 & -2.161 & -0.415 & -1.746 \\
\hline \multicolumn{4}{|c|}{$\begin{array}{c}\text { Descending Array } \\
\text { of Differences between F2 and } 4\end{array}$} & \multicolumn{4}{|c|}{$\begin{array}{c}\text { Descending Array } \\
\text { of Differences between F3 and } 4\end{array}$} \\
\hline No. & Type & 2 Type & $\begin{array}{c}4 \\
\text { Difference }\end{array}$ & No. & Type & 3 Type & Difference \\
\hline 18 & 1.291 & -0.985 & 2.277 & 18 & 1.658 & -0.985 & 2.644 \\
\hline 4 & 1.147 & -0.729 & 1.877 & 3 & 1.589 & -0.677 & 2.266 \\
\hline 2 & 1.814 & 0.284 & 1.530 & 15 & 1.587 & -0.340 & 1.926 \\
\hline 26 & 0.191 & -1.103 & 1.294 & 17 & 0.243 & -1.547 & 1.789 \\
\hline 17 & -0.265 & -1.547 & 1.282 & 22 & 1.430 & -0.175 & 1.605 \\
\hline 5 & 0.709 & -0.561 & 1.270 & 26 & 0.282 & -1.103 & 1.385 \\
\hline 11 & 0.628 & -0.444 & 1.072 & $9 i$ & 0.126 & -1.157 & 1.283 \\
\hline 3 & 0.249 & -0.677 & 0.927 & 24 & -0.415 & -1.662 & 1.247 \\
\hline 22 & 0.726 & -0.175 & 0.901 & 30 & -0.307 & -1.049 & 0.742 \\
\hline 10 & -0.255 & -0.951 & 0.696 & $19 \mathrm{~s}$ & 1.036 & 0.320 & 0.716 \\
\hline 6 & -0.181 & -0.459 & 0.278 & 7 & 1.710 & 1.123 & 0.588 \\
\hline 1 & 1.865 & 1.614 & 0.251 & 2 & 0.722 & 0.284 & 0.438 \\
\hline
\end{tabular}




\begin{tabular}{c|c|c|c|c|c|c|c}
\hline \multicolumn{3}{c}{$\begin{array}{c}\text { Descending Array } \\
\text { of Differences between F1 and 2 }\end{array}$} & \multicolumn{4}{c}{$\begin{array}{c}\text { Descending Array } \\
\text { of Differences between F 1 and 3 }\end{array}$} \\
\hline Number & Type & $\mathbf{1}$ Type & $\begin{array}{c}\mathbf{2} \\
\text { Difference }\end{array}$ & No. & Type & 1 Type & $\begin{array}{c}\text { 3 } \\
\text { Difference }\end{array}$ \\
\hline 15 & -0.099 & -0.340 & 0.240 & 31 & 0.589 & 0.388 & 0.201 \\
\hline 27 & 1.503 & 1.273 & 0.230 & 13 & -0.096 & -0.218 & 0.122 \\
\hline 19 & 0.510 & 0.320 & 0.190 & 27 & 1.210 & 1.273 & -0.063 \\
\hline 30 & -1.027 & -1.049 & 0.023 & 8 & -1.124 & -0.949 & -0.175 \\
\hline 9 & -1.193 & -1.157 & -0.036 & 11 & -0.681 & -0.444 & -0.237 \\
\hline 25 & -0.422 & -0.104 & -0.318 & 6 & -0.796 & -0.459 & -0.337 \\
\hline 8 & -1.329 & -0.949 & -0.380 & 10 & -1.378 & -0.951 & -0.427 \\
\hline 24 & -2.161 & -1.662 & -0.499 & 29 & 0.305 & 0.781 & -0.476 \\
\hline 31 & -0.201 & 0.388 & -0.589 & 4 & -1.404 & -0.729 & -0.675 \\
\hline 29 & 0.179 & 0.781 & -0.602 & 5 & -1.366 & -0.561 & -0.804 \\
\hline 13 & -0.862 & -0.218 & -0.644 & 28 & -0.120 & 0.833 & -0.953 \\
\hline 7 & 0.291 & 1.123 & -0.831 & 20 & 0.355 & 1.327 & -0.972 \\
\hline 23 & 1.255 & 2.224 & -0.969 & 14 & -0.992 & 0.056 & -1.048 \\
\hline 20 & 0.351 & 1.327 & -0.976 & 25 & -1.247 & -0.104 & -1.143 \\
\hline 16 & -0.685 & 0.442 & -1.126 & 16 & -0.797 & 0.442 & -1.238 \\
\hline 12 & -1.335 & -0.102 & -1.233 & 12 & -1.550 & -0.102 & -1.448 \\
\hline 28 & -0.495 & 0.833 & -1.328 & 32 & -0.633 & 0.953 & -1.586 \\
\hline 32 & -0.613 & 0.953 & -1.566 & 1 & -0.052 & 1.614 & -1.667 \\
\hline 21 & -0.018 & 1.597 & -1.614 & 21 & -0.149 & 1.597 & -1.746 \\
\hline 14 & -1.569 & 0.056 & -1.625 & 23 & 0.266 & 2.224 & -1.958 \\
\hline & & & & & & & \\
\hline
\end{tabular}

